\begin{tabular}{lccc} 
& GOSPODARKA & SUROWCAMI & MINERALNYMI \\
\hline Tom 28 & 2012 & Zeszyt 3 \\
& \multicolumn{2}{c}{ DOI $10.2478 / \mathrm{v} 10269-012-0026-\mathrm{y}$} &
\end{tabular}

\title{
Metoda prognozowania deformacji powierzchni terenu w rejonie zlóż gazu i ropy naftowej wraz $z$ analizą zagrożeń infrastruktury technicznej
}

\section{Wprowadzenie}

W rejonach eksploatowanych złóż ropy naftowej i gazu ziemnego, które wykazują właściwości kompakcyjne, może dochodzić do przemieszczeń i deformacji górotworu. Takie zjawisko ma miejsce tam, gdzie proces eksploatacji prowadzi do spadku ciśnienia porowego, a ciśnienie nadległych skał nie jest kompensowane przez zatłaczaną wodę (Teeuw 1973; Menghini 1989; Hejmanowski 1993). Zjawisko kompakcji jest dobrze rozpoznane, tym niemniej dopiero badania geologiczne i specjalne pomiary mogą potwierdzić, że skały budujące dane złoże wykazują tego typu właściwości. W przeszłości zjawiska kompakcji były przyczyną poważnych uszkodzeń infrastruktury kopalń otworowych, a nawet przyczyną znacznych nakładów np. na podnoszenie platform eksploatacyjnych (np. pole Ekofisk na Morzu Północnym, lata osiemdziesiąte XX w., podobne zagrożenie w Belridge (Kalifornia)). Deformacje górotworu doprowadziły w polu Ekofisk do uszkodzenia 2/3 otworów eksploatacyjnych. Miało to miejsce w głębi górotworu, kilkaset metrów nad złożem. W centralnej Kaliforni znaczna kompakcja zbiornika Belridge doprowadziła w latach osiemdziesiątych XX w. do powstania niecki obniżeniowej na powierzchni terenu o maksymalnych obniżeniach dochodzących do $6,1 \mathrm{~m}$. W brzeżnej części niecki na skutek wzrostu odkształceń poziomych wystąpiły liczne deformacje nieciągłe. Na skutek naprężeń

* Dr hab. inż., ** Dr inż., AGH Akademia Górniczo-Hutnicza, Wydział Geodezji Górniczej i Inżynierii Środowiska, Kraków; e-mail: hejman@agh.edu.pl; amalin@agh.edu.pl 
ścinających wystąiły w głębi górotworu liczne uszkodzenia otworów i infrastruktury eksploatacyjnej (Bondor, De Rouffignac 1995).

Eksploatacja złóż fluidalnych przyczynia się do wzrostu zagrożenia powierzchni terenu również w rejonach eksploatacji wód podziemnych. Tego typu eksploatacja ma miejsce na olbrzymią skalę na środkowym zachodzie Stanów Zjednoczonych, w Kaliforni, na terenach wielkich aglomeracji (np. Bangkok, Tokyo, Osaka, Szanghaj, Houston, Las Vegas), gdzie budynki i infrastruktura nie są $\mathrm{w}$ fazie wznoszenia zabezpieczane na deformacje rozciagające (Poland 1984).

Aby ocenić zagrożenie infrastruktury technicznej na terenach podlegających deformacjom podłoża stosuje się zazwyczaj metody eksperckie. Mają one zasadniczą wadę znaczny subiektywizm i uzależnienie wyniku od doświadczenia eksperta oceniającego odporność badanego obiektu na naprężenia wynikające $\mathrm{z}$ deformacji podłoża. Badania prowadzone przez autorów pozwoliły na wprowadzenie elementów sztucznej inteligencji do ocen zagrożenia budynków na terenach górniczych (Malinowska 2011). Dzięki zastosowaniu logiki rozmytej możliwa jest obiektywizacja procesu określania zagrożenia, a dalej także ryzyka dla obiektów budowlanych. Obecnie trwają prace nad zastosowaniem tego narzędzia dla obiektów infrastruktury liniowej, co znacznie powinno poprawić zdolności analityczne przy projektowaniu tras wodociągów, rurociągów ropy, benzyny, gazociągów oraz szlaków kolejowych i drogowych.

\section{Modelowanie obniżeń powierzchni terenu dla złóż gazu i ropy naftowej oraz wód podziemnych}

Przy założeniu, że znane są podstawowe parametry złoża eksploatowanego metodą otworowa, możliwe jest zastosowanie zaadaptowanej formuły teorii geometryczno-całkowej do modelowania przemieszczeń pionowych w górotworze i na powierzchni terenu (Hejmanowski 1993, 1995). Algorytm obliczeniowy oparty jest na zasadzie dyskretyzacji całego złoża w granicach, w jakich występować będzie w czasie eksploatacji spadek pierwotnego ciśnienia porowego. Każdy z elementów złożowych ma przypisane lokalne parametry, istotne dla procesu modelowania przemieszczeń w czasie. Są to przykładowo: grubość pakietu eksploatowanych skał porowatych, pierwotne ciśnienie złożowe, ciśnienie przewidywane po czasie $t$ (rys. 1).

Elementarne przemieszczenie pionowe, które jest efektem spadku pierwotnego ciśnienia porowego w elemencie złoża można wyznaczyć korzystając z zależności (1):

$$
\Delta w_{t}(R, \Delta t)=\frac{a \cdot \Delta M(\Delta t) \cdot L^{2}}{r^{2}} \cdot \exp \left(-\pi \frac{R^{2}}{r^{2}}\right)
$$

Ponieważ takie obniżenie występuje wskutek kompakcji skały porowatej, funkcja kompakcji występująca w równaniu (1) dana jest zależnością (2): 


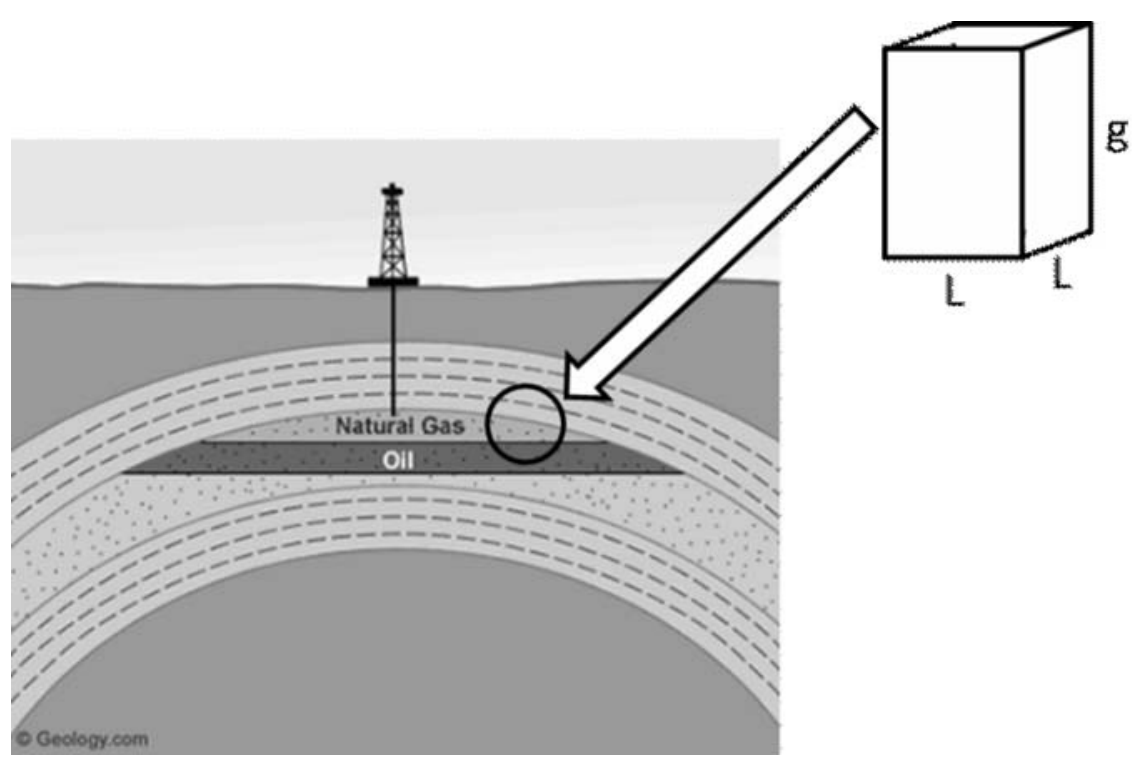

Rys. 1. Schemat podziału złoża na elementy (obraz geologii złoża za (Geology.com ))

Fig. 1. Dividing an gas reservoir in elementary parts (picture of the reservoir geology from (Geology.com))

$$
\Delta M(\Delta t)=c_{m} \cdot\left(p_{o_{i}} \cdot p_{i}(\Delta t)\right) \cdot g_{i}
$$

gdzie:

a $\quad-$ współczynnik zmniejszenia objętości elementarnej pustki w górotworze,

$\Delta M(\Delta t) \quad-$ kompakcja,

$\Delta t \quad-$ różnica czasu od początku eksploatacji elementu złożowego do momentu obliczeniowego $t$,

$p_{0 i} \quad-$ pierwotne ciśnienie porowe w $i$-tym elemencie złożowym, w chwili rozpoczęcia eksploatacji,

$p_{i}(\Delta t) \quad-$ ciśnienie porowe w $i$-tym elemencie złożowym w chwili $t$,

$g_{i} \quad-$ grubość złoża w elemencie złożowym,

$R \quad$ - odległość punktu obliczeniowego od środka geometrycznego elementu złożowego,

L - długość boku elementu złożowego,

$r \quad-$ promień rozproszenia oddziaływania eksploatacji elementarnej,

$c_{m} \quad-$ współczynnik kompakcji, charakteryzujący kompakcyjność skał złoża (Teeuw 1973; Menghini 1989)

Sumaryczne oddziaływanie całej eksploatacji złoża na dany punkt górotworu lub powierzchni terenu można wyznaczyć jako sumę oddziaływań elementarnych w danej chwili $t$. 


$$
w(R, \Delta t)=\sum_{i=1}^{N} \Delta w_{i}(R, \Delta t)
$$

Dysponując wartościami obniżeń możliwe jest wyznaczenie pozostałych wskaźników deformacji, tj. nachyleń $(T)$ oraz krzywizn $(K)$ tworzącej się niecki obniżeniowej jako pierwszej i drugiej pochodnej obniżeń (Hejmanowski, Kwinta 2010). Wskaźniki związane ze składową poziomą: przemieszczenia poziome $(u, v)$ i odkształcenia poziome $(\varepsilon)$ można wyznaczać z wykorzystaniem zależności:

$$
\Delta u=-B \cdot T
$$

$$
\Delta \varepsilon=-B \cdot K
$$

gdzie:

$B$ - tzw. współczynnik przemieszczenia poziomego Awierszyna,

$$
B \cong \frac{r}{\sqrt{2 \pi}}
$$

Niecki obniżeniowe wykształcające się w rejonach eksploatacji złóż gazu ziemnego i ropy naftowej cechuje zazwyczaj duży promień rozproszenia wpływów $r$, a więc duży zasięg, znacznie wykraczający poza granice złoża. To sprawia, że obniżenia maksymalne nie osiagają zbyt znacznych wartości. Zatem także deformacje w rejonie kluczowym z punktu widzenia przedsiębiorcy (czyli otworu pionowego, głównego) nie stanowią przeważnie istotnego zagrożenia. Problemy z infrastrukturą otworów występują z tytułu dużych obniżeń w centrum niecki, co ma miejsce przy dużych miąższościach złóż i eksploatacji prowadzonej bez zastosowania profilaktyki obniżeniowej.

\section{Zastosowanie sztucznej inteligencji do oceny zagrożenia obiektów}

W odróżnieniu od terenów podlegających wpływom eksploatacji węgla kamiennego, czy rud metali, eksploatacja złóż surowców gazowych i ciekłych odbywa się w rejonach, których zabudowa i infrastruktura powierzchniowa nie są odpowiednio zabezpieczone przed deformacjami. Z tego względu uszkodzenia, które mają miejsce w trakcie eksploatacji złoża, są znaczne i często nawet zagrażają bezpieczeństwu użytkowników, pomimo stosunkowo niewielkich bezwzględnych wartości odkształceń poziomych. 


\subsection{Możliwość zastosowania logiki rozmytej}

\subsubsection{Założenia modelu rozmytego}

Ocena zagrożenia uszkodzeniami obiektów poddanych wpływom deformacji powierzchni terenu jest procesem wieloetapowym. Złożoność ta wynika z szeregu czynników, które wpływają na dokładność ostatecznej oceny zagrożenia obiektów, takich jak (Hejmanowski, Malinowska 2007, 2009):

— wiarygodność, aktualność, dokładność informacji o czynnikach górniczo-geologicznych generujących przekształcenia powierzchni terenu,

— dokładność modeli prognostycznych wykorzystanych do estymacji deformacji powierzchni terenu,

— aktualność i dokładność parametrów modeli prognostycznych,

— aktualność, wiarygodność informacji o czynnikach wpływających na odporność obiektów,

— dokładność metody oceny odporności obiektów,

— subiektywność specjalistów szacujących deformacje powierzchni terenu oraz odporność obiektów,

— trafność przyjętych kryteriów oceny zagrożenia obiektów.

W świetle powyższych czynników należy mieć świadomość, że ostateczny wynik oceny zagrożenia obiektów poddanych wpływom deformacji powierzchni terenu jest zmienną obciążoną bardzo dużą niepewnością. Cytując za twórcą logiki rozmytej Zadeh'em słuszne jest stwierdzenie, że (Zadeh 1965): „Złożoność i precyzja występują w zależności odwrotnej w tym sensie, że jeżeli złożoność rozpatrywanego problemu wzrasta, to zmniejsza się możliwość jej precyzyjnej analizy"

Powyższe przesłanki oraz stale rosnące niezadowolenie $\mathrm{z}$ obecnie stosowanych metod oceny zagrożenia obiektów na terenach podlegających deformacjom stały się punktem wyjścia do nowych badań. Badania te oparte są na elementach wnioskowania rozmytego, a narzędziem wspierającym integrację danych, weryfikację ich wiarygodności i wykonywanie analiz będzie GIS (Geographic Information System). Idea wykorzystania logiki rozmytej przy ocenie zagrożenia obiektów będących pod wpływem deformacji pozwala na uwzględnienie niepewności zmiennych jakimi są zagrożenie (generowane przez ciągłe deformacje powierzchni terenu) i odporność (wynikająca z eksperckiej oceny odporności obiektów budowlanych czy infrastruktury liniowej).

Proponowana metoda pozwala na ocenę ryzyka wystąpienia w obiekcie szkody górniczej. Poniżej zostaną przedstawione tylko podstawowe założenia tej metody, szczegółowe założenia i etapy budowy systemu rozmytego przedstawiono w artykule (Malinowska 2011). Algorytm postępowania zakłada pozyskanie informacji o czynnikach górniczo-geologicznych, a następnie określenie maksymalnych deformacji powierzchni terenu pod każdym z obiektów. Czynnikiem determinującym zagrożenie dla mieszkalnych obiektów kubaturowych jest odkształcenie poziome. Jest to pierwsza zmienna rozmytego modelu wniosku- 
jącego. Odporność obiektów budowlanych na terenach górniczych oceniana jest najczęściej przy wykorzystaniu punktowej metody (Przybyła, Świądrowski 1968). W wyniku estymacji wytrzymałości budynków tą metodą każdemu obiektowi przypisana zostaje punktowa wartość odporności na odkształcenia poziome. Odwrotność odporności czyli wrażliwość jest drugą zmienną niezbędną do rozmytej oceny zagrożenia szkodą budynków. Uwzględnienie niepewności w estymacji zagrożenia wystąpieniem szkody w budynkach odbywa się w procesie wnioskowania rozmytego. W celu określenia zmiennej wyjściowej zdefiniowano na nowo pojęcie, którym było zagrożenie uszkodzeniem obiektu budowlanego wyrażane w skali punktowej. Zmienna ta pozwoli na punktowe określenie stopnia zagrożenia uszkodzeniem budynku, które może prowadzić do zagrożenia bezpieczeństwa użytkowania.

Pierwszym etapem budowy rozmytego systemu wnioskowania było zdefiniowanie przestrzeni rozważań dla zmiennych wejściowych i wyjściowych. Przyjęto, że prognozowane ekstremalne odkształcenia poziome, mogą przyjmować wartości z przedziału $[0,20] \mathrm{mm} / \mathrm{m}$, gdzie wartości liczbowe wyznaczane są z dokładnością do dwóch miejsc po przecinku (rys. 2). Odporność obiektu budowlanego określana na podstawie metody punktowej może przyjmować teoretycznie od 0 do 150 punktów, jednak w rzeczywistości obiekty budowlane nie mają więcej niż 100 punktów odpornościowych. Dlatego przedział dla zmiennej określający wrażliwość budynków na terenach górniczych ograniczono, definiując go w granicach $[0,100]$ (rys. 3). Zmienna wyjściowa, którą jest zagrożenie uszkodzeniem obiektu budowlanego, charakteryzowana jest przez punkty, mogące przyjmować wartości od 0 do 100 (rys. 4). Kolejno określono zmienne lingwistyczne dla zbiorów rozmytych i zdefiniowano kształt funkcji przynależności dla tych zmiennych.

Dalszym etapem wnioskowania rozmytego jest rozmycie ostrych wartości zmiennych wejściowych w procesie fuzyfikacji (rys. 2, 3). Tym samym zostaje określony ich stopien

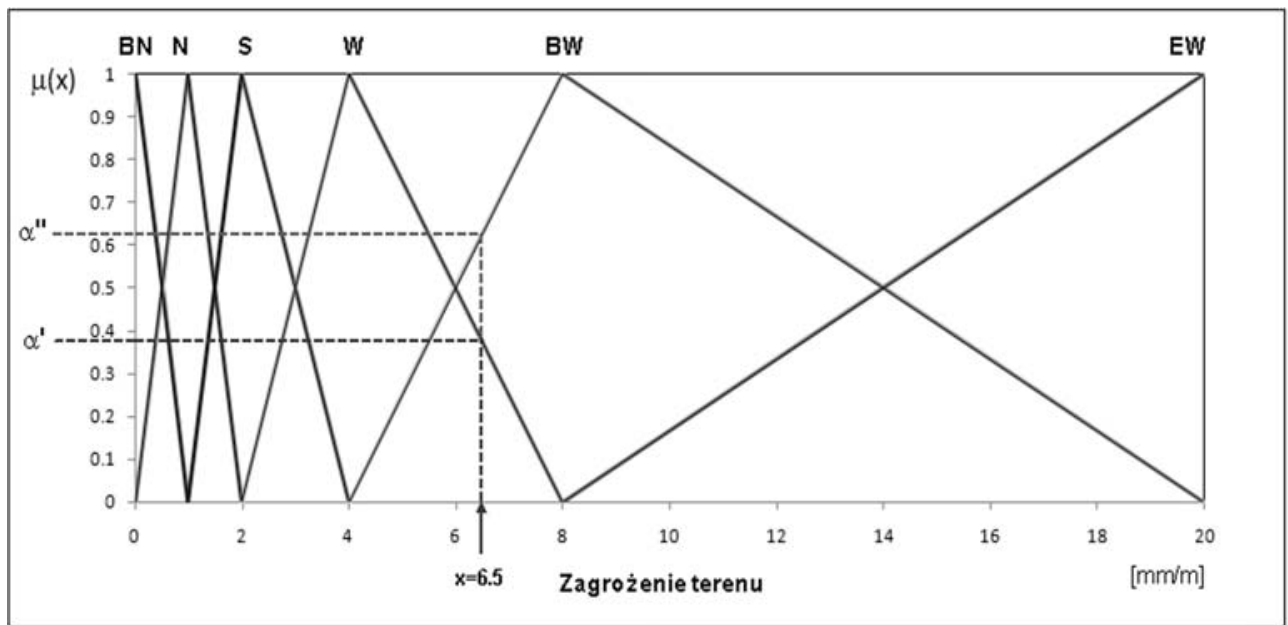

Rys. 2. Rozmycie ostrej wartości zagrożenia terenu

Fig. 2. Fuzzification of crisp values of surface hazard into grades of membership for linguistic terms of fuzzy sets 


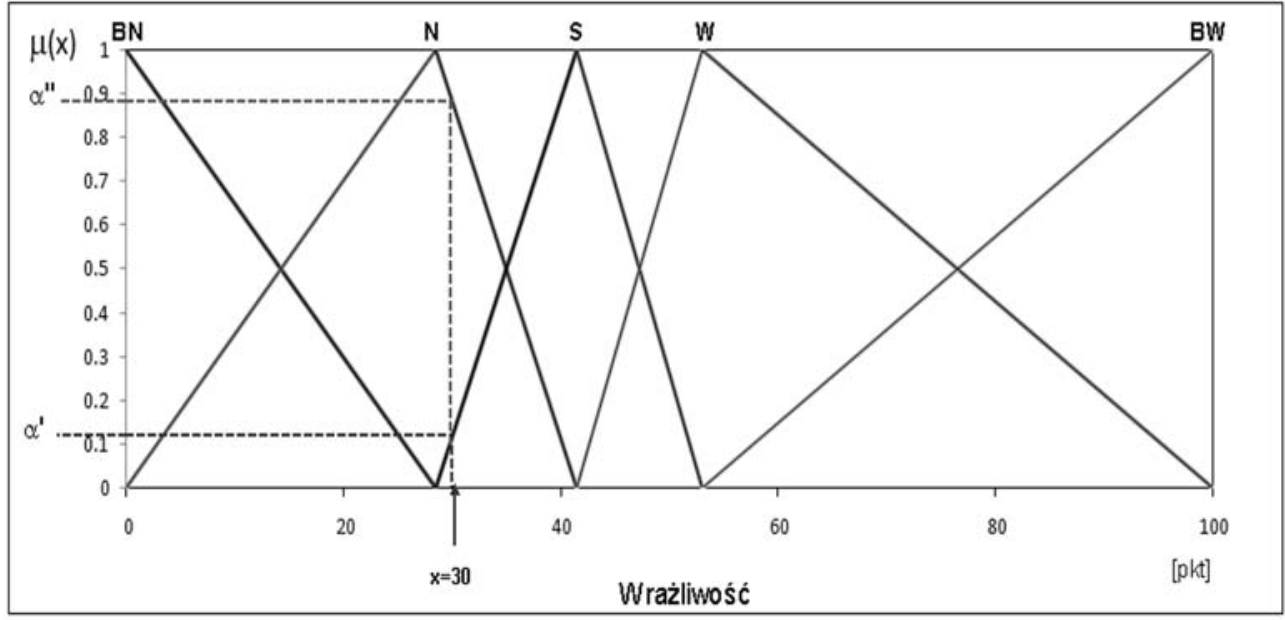

Rys. 3. Rozmycie ostrej wartości wrażliwości obiektu budowlanego

Fig. 3. Fuzzification of crisp values of building vulnerability into grades of membership for linguistic terms of fuzzy sets

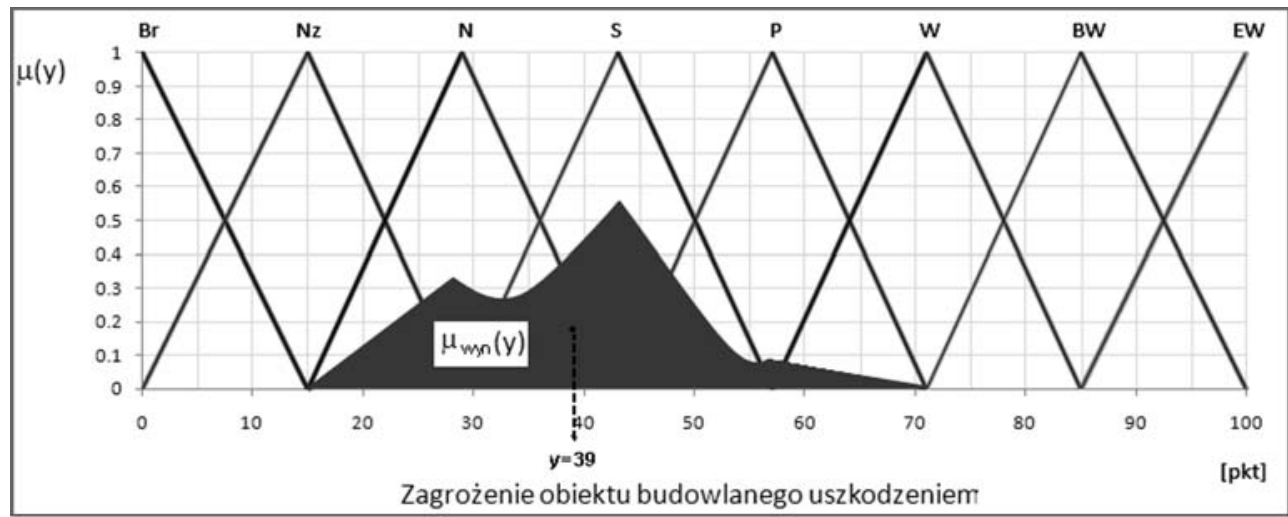

Rys. 4. Określenie ostrej wartości zagrożenia obiektu budowlanego uszkodzeniem

Fig. 4. Estiamtion crisp value of hazard of building damage

przynależności do zbiorów rozmytych w dziedzinach zagrożenie terenu i wrażliwość obiektu. Na tym etapie ujęta zostaje niepewność wynikająca z niedokładności danych górniczo-geologicznych, modeli, parametrów i eksperckich ocen odporności obiektów budowlanych.

Następnym etapem jest proces inferencji, w którym na podstawie rozmytych danych wejściowych określany jest stopień spełnienia przesłanek. Z przesłanek z kolei wynika stopień spełnienia konkluzji dla poszczególnych reguł (Shahinkar i in. 2008). Najistotniejszym elementem tego procesu jest baza reguł, w której określone są wszystkie zależności pomiędzy zmiennymi wejściowymi i wyjściowymi (tab. 1). 
Aktywacja reguł w bazie

Activation rules in the rule base

\begin{tabular}{|c|c|c|c|c|c|c|c|c|}
\hline & & & \multicolumn{6}{|c|}{ Zagrożenie terenu } \\
\hline & & & 0 & I & II & III & IV & $\mathrm{V}$ \\
\hline \multirow{6}{*}{ 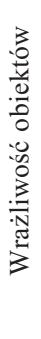 } & & & $\mathrm{BN}$ & $\mathrm{N}$ & S & $\mathbf{W}$ & BW & EW \\
\hline & 4 & $\mathrm{BN}$ & Brak & Brak & Brak & Nieznaczne & Niskie & Średnie \\
\hline & 3 & $\mathbf{N}$ & Brak & Brak & Nieznaczne & Niskie & Średnie & Poważne \\
\hline & 2 & $\mathbf{S}$ & Brak & Nieznaczne & Niskie & Średnie & Poważne & Wysokie \\
\hline & 1 & $\mathrm{~W}$ & Nieznaczne & Niskie & Średnie & Poważne & Wysokie & B. Wysokie \\
\hline & 0 & BW & Niskie & Średnie & Poważne & Wysokie & B. Wysokie & Ekstr. Wysokie \\
\hline
\end{tabular}

Kolejnym etapem jest proces agregacji, w którym tworzona jest wynikowa funkcja przynależności. Ten i poprzedni etap ujmują rozmytość, wynikającą z niepewności zależności pomiędzy zmiennymi.

Ostatnim etapem wnioskowania jest określenie punktowej wartości zagrożenia wystąpieniem szkody górniczej. Estymacja ta przeprowadzana jest w procesie defuzyfikacji (rys. 4).

Punktowa ocena zagrożenia stanowi przesłankę do podjęcia decyzji o dalszym postępowaniu. Opisany powyżej proces wnioskowania rozmytego przeprowadzony został przy wykorzystaniu pakietu MatlabFuzzytoolbox (MathWorks). Istnieje jednak szereg programów open source dedykowanych sztucznej inteligencji, które również pozwalają na zaimplementowanie tego modelu.

Propozycja wykorzystania w praktyce zaprezentowanej metody polega na integracji modelu w systemie informacji geograficznej. Tym samym ocena zagrożenia obiektów będzie przeprowadzona automatycznie. Ma to szczególnie duże znaczenie na rozległych terenach będących w zasięgu wpływów działalności górniczej, które są intensywnie zagospodarowane. Znaczenie to wzrośnie dodatkowo dla rejonów eksploatacji gazu ziemnego i ropy naftowej i dużych zasięgów tworzących się w takich warunkach niecek obniżeniowych. Schemat postępowania przy ocenie zagrożenia obiektów projektowanym wydobyciem przedstawiono poniżej.

\subsubsection{Zastosowanie praktyczne}

Przedsiębiorca górniczy planując eksploatację zobligowany jest do oceny zagrożenia obiektów znajdujących się w zasięgu wpływów projektowanej eksploatacji (Dz.U. z dnia 1 lipca 2002 r.). Dlatego w każdym nowym rejonie, który jest zabudowany, a przewidywane jest szkodliwe oddziaływanie na powierzchni prowadzonych robót górniczych, 
konieczne jest przeprowadzenie inwentaryzacji tych obiektów. Każdemu z obiektów nadana zostaje odporność przy wykorzystaniu metody punktowej. Dane dotyczące obiektów zintegrowane zostają w systemie GIS (rys. 5).

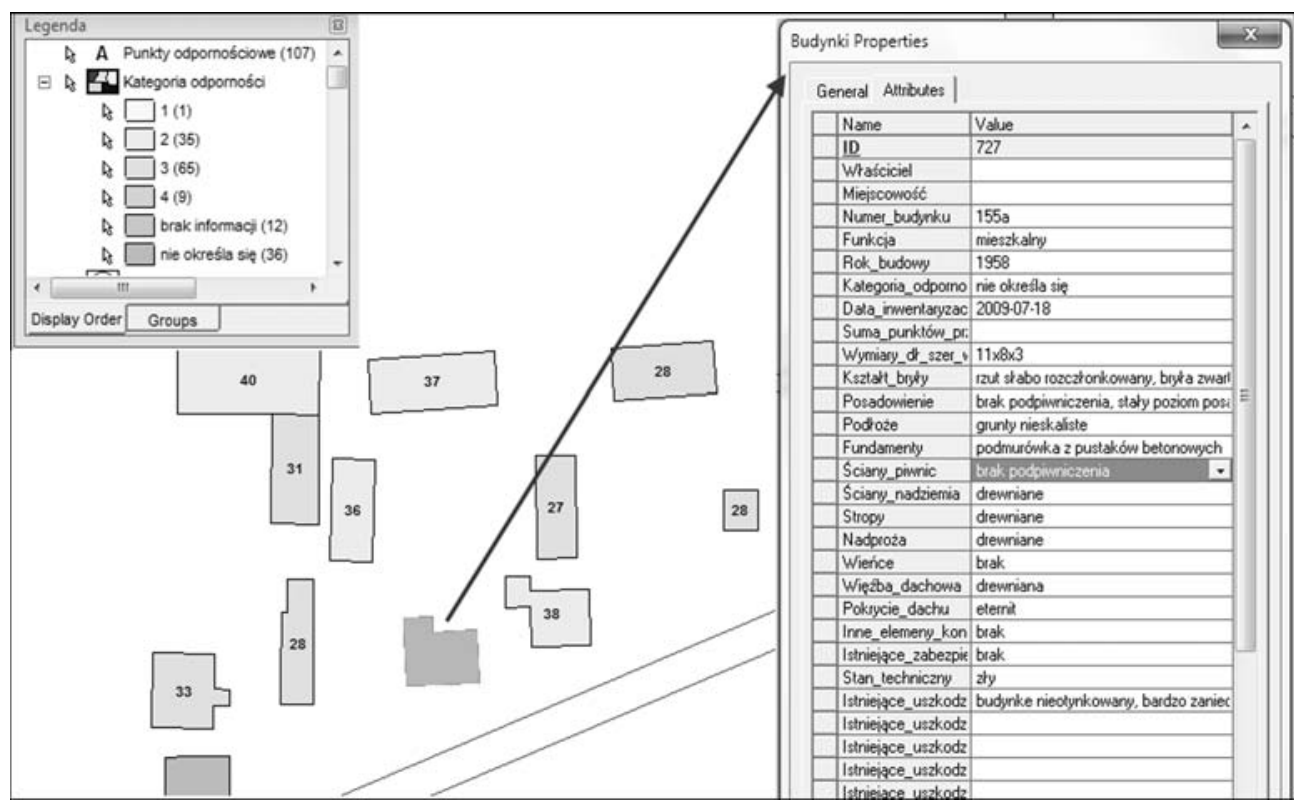

Rys. 5. Integracja danych w GIS

Fig. 5. Data integration in GIS

Przedsiębiorca górniczy zobligowany jest również do określenia zagrożenia, jakie może wystapić na powierzchni terenu. W tym celu musi on sporządzić ,prognozę wpływu działalności górniczej na przeobrażenia w środowisku. Przewidywany wpływ eksploatacji górniczej na powierzchnię w całym okresie prowadzenia ruchu zakładu górniczego" (Dz.U. z dnia 1 lipca 2002 r.). W części szczegółowej do planu ruchu określone są typy zagrożeń, których prognozę należy sporządzić, a jednym z nich są deformacje ciąłe. Tego typu prognoza dla eksploatacji złóż fluidalnych scharakteryzowana została w rozdziale 1. Baza danych GIS zostaje zasilona danymi dotyczącymi przewidywanych deformacji ciągłych w zasięgu wpływów szkodliwych. Dla każdego obiektu budowlanego zostają wyznaczone maksymalne wskaźniki deformacji, które stanowią dla niego potencjalne zagrożenie (rys. 6).

Opierając się na powyższych informacjach przy wykorzystaniu rozmytego modelu wnioskującego możliwe jest określenie ilości punktów świadczących o zagrożeniu danego obiektu szkodą górniczą (rys. 7).

Zaprezentowana metoda pozwala przede wszystkim na szybką ocenę zagrożenia uszkodzeniem dużej ilości obiektów oraz uwzględnienie niepewności w ocenie zagrożenia wystąpieniem szkody górniczej. 


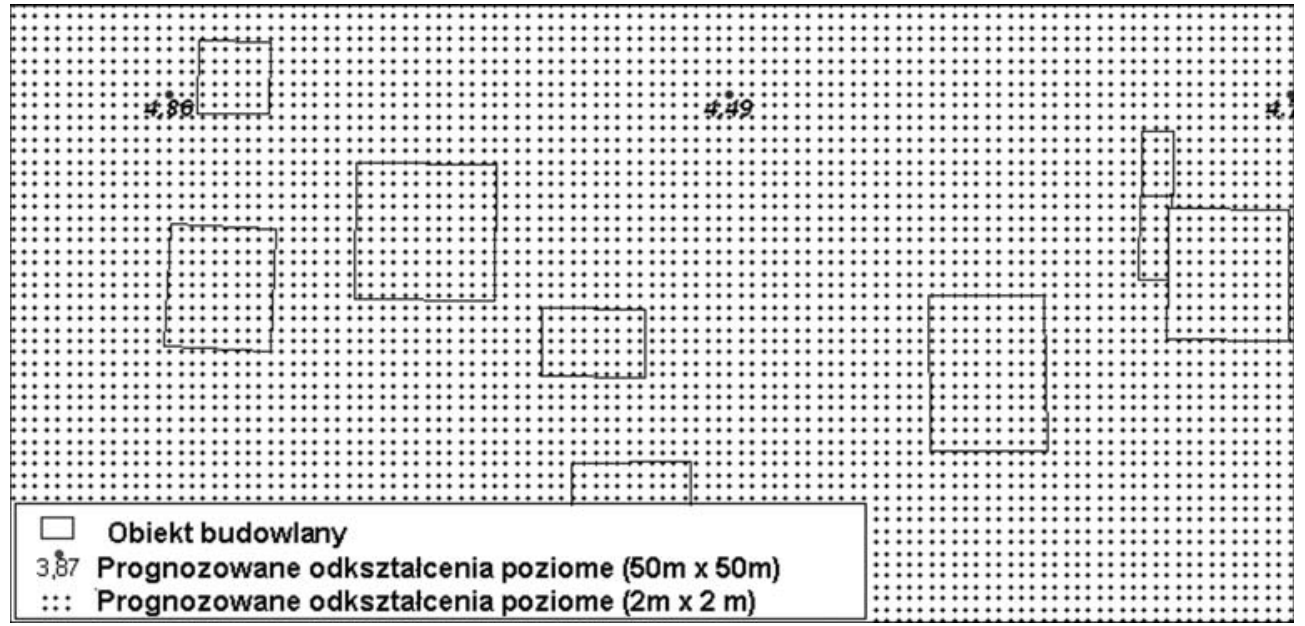

Rys. 6. Prognozowane odkształcenie poziome, główne

Fig. 6. Surface deformation - predicted

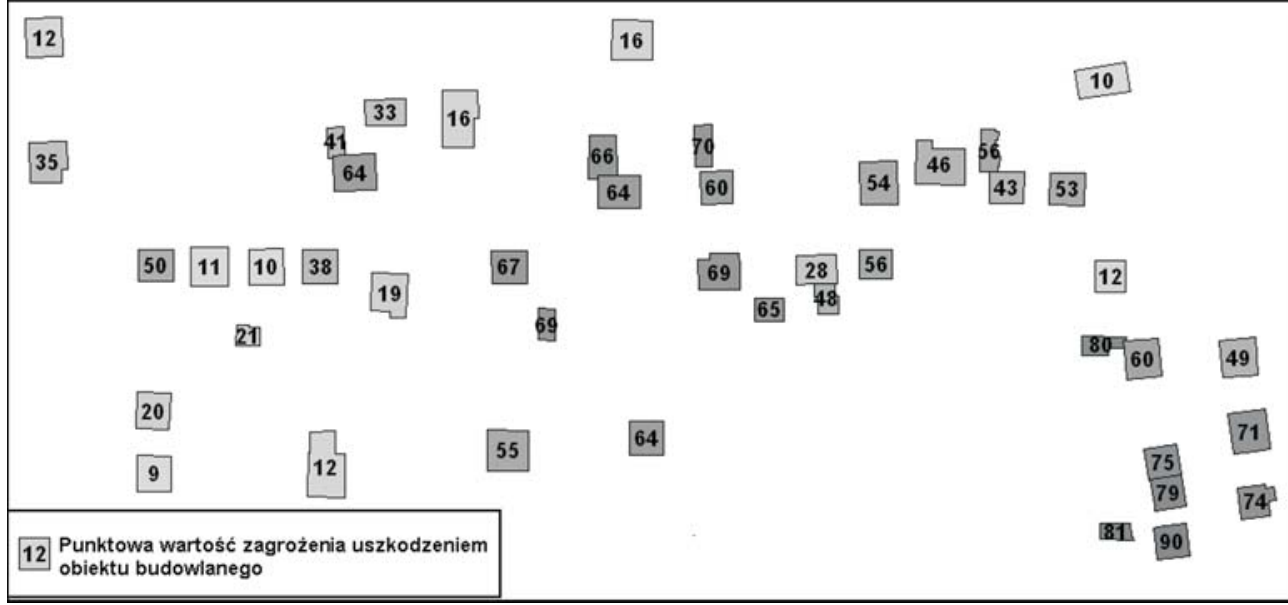

Rys. 7. Wyniki oceny zagrożenia obiektów

Fig. 7. Results of buildings hazard estimation

\subsection{Perspektywy dalszych badań - infrastruktura liniowa}

Metoda przedstawiona w poprzednim rozdziale dotyczy jedynie obiektów budowlanych spełniających kryteria, które umożliwiają oszacowanie ich odporności metodą punktową. Badania aktualnie prowadzone $\mathrm{w}$ ramach projektu badawczego mają na celu opracowanie metody zagrożenia obiektów liniowych zlokalizowanych na terenach podlegających 
deformacjom w uwzględnieniu niepewności. Problemy wielokrotnie poruszane przez ekspertów to (Skinderowicz 1975; Mokrosz 2010):

- brak kierunkowości w estymacji deformacji zagrażającym tym obiektom,

- subiektywizm oceny odporności obiektów liniowych,

- brak jasnych kryteriów granicznych przy szacowaniu ryzyka uszkodzeniem,

- niedokładność prognoz deformacji powierzchni generowana przez zmienne wymienione $\mathrm{w}$ poprzednim rozdziale,

- nieuwzględnianie istotności obiektów liniowych,

- brak uwzględnienia okresu, w jakim deformacje będą osiagały wartości maksymalne (np. w przypadku odkształceń poziomych),

— rozległość obiektów liniowych (w sensie przestrzennym).

Przy wykorzystaniu metod sztucznej inteligencji i systemów informacji geograficznej podjęta zostanie próba częściowego rozwiązania powyższych problemów.

Badania zostały zrealizowane w ramach grantu Narodowego Centrum Nauki, nr UMO-2011/-1/ST10/06958.

\section{LITERATURA}

B ond or P.L., De R o uffig n a E., 1995 - Land subsidence and well failure in the Belridge diatomite oil field, Kern county, California. Part II. Applications. Proceedings of the fifth international symposium on land subsidence FISOLS'95 (ed. by F.B.J. Barends, F.J.J. Brouwer, F.H).

Hejmanowski R., 1993 - Zur Vorausberechnung förderbedingter Bodensenkungen über Erdöl- und Erdgaslagerstätten. Doctor'sthesis, Technical University Clausthal, Clausthal-Zellerfeld. (ger.)

Hej man owski R., 1995 - Prediction of surface subsidence due to oil- or gasfield development. Proceedings of the fifth international symposium on land subsidence FISOLS'95 (ed. by F.B.J. Barends, F.J.J. Brouwer, F.H).

Hejmanowski R., Malinowska A., 2007 - Ocena wiarygodności prognozy przemieszczeń pionowych w oparciu o przestrzenną analizę statystyczną. WUG: Bezpieczeństwo pracy i ochrona środowiska w górnictwie, $\mathrm{nr} 2$.

Hejmanowski R., Malinowska A., 2009 - Evaluation of reliability of subsidence prediction based on spatial statistical analysis, International Journal of Rock Mechanics and Mining Sciences Vol. 46, Issue 2, pp. 432-438.

Hej manowski R., Kwinta A., 2010 - Modelowanie deformacji ciagłych powierzchni terenu w warunkach zmiennego zalegania złoża. Gospodarka Surowcami Mineralnymi t. 26, z. 3.

Malin owska A., 2011 - A fuzzy inference-based approach for building damage risk assessment on mining terrains. Engineering Structures. Vol. 33, Issue 1.

Menghini M.L., 1989 - Compaction monitoring in the Ekofisk area chalk fields. Journal of Petroleum Technology, July .

Mokros z R., 2010 - Oczekiwania dotyczące prognoz wpływów eksploatacji górniczej dla celów projektowania obiektów budowlanych. Konferencja: Bezpieczeństwo i ochrona obiektów budowlanych na terenach górniczych/konferencja naukowo-szkoleniowa, Wyd. GIG, Katowice.

P o l a n d J.F., 1984 - Guidebook to studies of land subsidence due to ground-water withdrawal. UNESCO. Paris.

Przybyła H., Świądrowski W., 1968 - Określenie kategorii odporności istniejących obiektów budownictwa powszechnego na wpływy eksploatacji górniczej. OTG nr 8, Katowice.

Rozporządzenie Ministra Spraw Wewnętrznych i Administracji z dnia 14 czerwca 2002 r.w sprawie planów ruchu zakładów górniczych (Dz.U. z dnia 1 lipca 2002 r.). 
Shahinkar A., Shahriar K., Asadi A., Akbari A.D., 2008 - Feasibility study of oil mining - a fuzzy AHP decision making approach. Gospodarka Surowcami Mineralnymi t. 24, z. 4/2.

Skinderowicz B., 1975 - Projektowanie eksploatacji pokładów węgla pod trasami kolejowymi. Materiały konferencyjne: Wybrane problemy ochrony obiektów kolejowych na terenach górniczych. Wyd. Zespół Wydawniczy Zarządu Oddziału SITG, Katowice.

Teeuw D., 1973 - Laboratory measurement of compaction properties of Groningen reservoir rock. Verhandlingen Kon. Ned. Gel. Min. Gen., DEEL Vol. 28.

Za de h L.A., 1965 - Fuzzysets. Information and Control, vol. 38, No. 1, pp 1-14

Geology.com - portal internetowy

The MathWorks: http://www.mathworks.com/access/helpdesk/help/toolbox/fuzzy/

METODA PROGNOZOWANIA DEFORMACJI POWIERZCHNI TERENU W REJONIE ZLÓŻ GAZU I ROPY NAFTOWEJ WRAZ Z ANALIZĄ ZAGROŻEŃ INFRASTRUKTURY TECHNICZNEJ

Słowa kluczowe

Logika rozmyta, modelowanie, deformacje górotworu, eksploatacja gazu, ropa naftowa

\section{Streszczenie}

Eksploatacja złóż gazu ziemnego i ropy naftowej w pewnych warunkach zalegania tych złóż może wywoływać deformacje ciagłe powierzchni terenu. Deformacje takie objawiają się w postaci niecek obniżeniowych o znacznym zasięgu i maksymalnych obniżeniach zależnych od całkowitej miąższości basenu, właściwości kompakcyjnych skał i szeregu innych czynników. W historii zdarzały się niecki o maksymalnych obniżeniach dochodzących do 9 metrów. W niecce obniżeniowej występują także strefy naprężeń niebezpieczne dla infrastruktury technicznej i budynków. Deformacje takie mogą wpływać niekorzystnie na budynki i budowle, ale także na infrastrukturę własną zakładów górniczych. Znane są przypadki zniszczenia otworów i ich uzbrojenia, bądź utraty ich szczelności. Z uwagi na to istnieje konieczność wykonywania analizy możliwości wystapienia takich niekorzystnych zjawisk, monitorowania deformacji w trakcie eksploatacji złoża i ochrony infrastruktury zlokalizowanej w zasięgu wpływów eksploatacji. W artykule przedstawiona jest problematyka prognozowania deformacji powierzchni w warunkach eksploatacji złóż surowców ciekłych i gazowych. Przyjęto założenie o związku przyczynowo-skutkowym między kompakcją skały basenu a obniżeniem powierzchni terenu. Model obliczeniowy oparto na tzw. funkcji wpływów i superpozycji wpływów elementarnych. Dla celów ochrony obiektów i infrastruktury opracowany został model oceny zagrożenia obiektów bazujący na elementach logiki rozmytej. Model ten pozwala na uwzględnienie w analizach czynników ilościowych i jakościowych determinujących zagrożenie uszkodzeniem. Dzięki temu możliwe jest uzyskanie jednoznacznej wartości różnicującej zagrożenie poszczególnych budynków na danym terenie. Analizy przestrzenne, które pozwalają na uwzględnienie dużej ilości budynków mogą być wspomagane poprzez zastosowanie systemów GIS. W artykule zostało to zilustrowane na przykładzie praktycznym.

METHOD OF SURFACE DEFORMATIONS PREDICTION IN THE NATURAL GAS AND PETROLEUM MINING AREAS WITH TECHNICAL INFRASTRUCTURE RISK ASSESSMENT METHOD

Key words

Fuzzy logic, modeling, roc mass deformation, natural gas, oil development 


\section{Abstract}

Hydrocarbon production under certain geological conditions of these deposits can cause surface subsidence and deformation of the terrain surface. Such deformations appear as subsidence troughs of considerable range and the magnitude of the subsidence depending on the total thickness of the reservoir, compaction properties of reservoir and on the number of other factors. In the past there have been widely recognized magnitudes of the subsidence up to 9 meters. The stress zones in the subsidence trough may affect the buildings and surface structures. However there have been well known some cases of destroyed boreholes or pipelinesbelonging to thegas or oil mine.Therefore there is a requirement to analyze the possibility of occurrence unfavorable phenomenon on the ground surface, to monitor surface deformations during production and to protect surface infrastructure located in the range of mining influences.

In the paper the issue of surface subsidence caused by hydrocarbon production has been presented. The cause effect relationship between the compaction of thereservoir rock and the subsidence of surface area has been assumed. The prediction model base on the influence functionand on the superposition of elementary influences.

For the purpose of building damage protection a new model of risk assessment has been developed. This model base on the elements of fuzzy logicallows to incorporate in the analysis the quantitative and qualitative factors that contribute to the risk of building damage. Use of the fuzzy logic made it possible to obtain onevalue which clearlydiscriminate the risk of buildings damage. However, risk analyzes of damage to the large number of buildings has been required additional tools. The spatial analysishas been made by using GIS. The subjects of the paperhave been illustrated with a practical example. 
